\title{
Pengaruh Pembelajaran Kooperatif Tipe Group Investigation (GI) Terhadap Kemampuan Pemecahan Masalah Matematis Dan Percaya Diri Siswa SMP Negeri 2 Rembang
}

\author{
Khotijah Priyatin \\ Program Studi Pendidikan Matematika Universitas Muhammadiyah Purwokerto \\ khotijahpriyatin@gmail.com
}

\begin{abstract}
ABSTRAK
Penelitian ini bertujuan untuk mengetahui pengaruh pembelajaran kooperatif tipe Group Investigation terhadap kemampuan pemecahan masalah matematis dan percaya diri siswa kelas VII SMP Negeri 2 Rembang tahun ajaran 2017/2018. Populasi pada penelitian ini adalah siswa kelas VII SMP Negeri 2 Rembangtahun ajaran 2017/2018. sampel pada penelitian ini adalah kelas VIIE sebagai kelas Eksperimen dan VII C sebagai kelas Kontrol yang diambil dengan teknik Cluster Random Sampling. Instrumen yang digunakan dalam penelitian ini berupa Post test. Hasil post test diperoleh setelah siswa pada kelas eksperimen mengikuti pembelajaran kooperatif tipe Group Investigationdan kelas kontrol mengikuti pembelajaran langsung. Hasil post testdiolah menggunakan bantuan Software IBM SPSS Statistic 21 dengan melakukan uji Mann Whitney untuk hasil post test dan uji Independent t Test pada hasil angket. Diperoleh nilai sig pada uji Mann Whitney untuk hasil post test sebesar 0,0355 dan nilai sig pada uji Independent t Testuntuk hasil angket sebesar 0,0075 nilai dari kedua uji tersebut kurang dari $\alpha(0,05)$, Sehingga mengakibatkan H0 ditolak. Jadi Disimpulkan bahwa model pembelajaran Group Investigationberpengaruh terhadap kemampuan pemecahan masalah dan percaya diri siswa di SMP Negeri 2 Rembang.
\end{abstract}

Kata kunci: kemampuan pemecahan masalah matematis, percaya diri siswa dan Pembelajaran kooperatif tipe Group Investigation.

\begin{abstract}
This study aims to determine the effect of Group Investigation type cooperative learning on mathematical problem solving abilities and confidence of class VII students of Rembang 2 State Junior High School $2017 / 2018$ school year. The population in this study were seventh grade students of Rembang 2 State Junior High School 2017/2018 school year. The sample in this study is class VII E as the Experiment class and VII C as the Control class which is taken by Cluster Random Sampling technique. The instrument used in this study is post test. Post test results were obtained after students in the experimental class followed Group Investigation cooperative learning and the control class followed direct learning. Post test results were processed using IBM SPSS Statistic 21 Software by performing the Mann Whitney test for post test results and Independent $t$ Test tests on questionnaire results. The sig value obtained on the Mann Whitney test for post test results is 0.0355 and the sig value on the Independent t-test for the results of the questionnaire is 0.0075 . So it can be concluded that students' mathematical problem solving and self-confidence abilities that follow Group Investigation type cooperative learning are better than mathematical problem solving abilities and confidence by using direct learning.
\end{abstract}

Key words: mathematical problem solving ability, student confidence and Group Investigation type cooperative learning

\section{Pendahuluan}

Matematika adalah salah satu ilmu pendidikan yang sangat penting bagi kehidupan Manusia, salah satunya dalam bidang pendidikan. Oleh karena itu, Matematika salah satu pelajaran 


\section{KHOTIJAH PRIYATIN}

Pengaruh Pembelajaran Kooperatif Tipe Group Investigation (GI) Terhadap Kemampuan Pemecahan Masalah Matematis Dan Percaya Diri Siswa SMP Negeri 2 Rembana

pokok pelajaran pokok di sekolah baik sekolah dasar, sekolah lanjutan sampai ke perguruan tinggi. Hal ini dapat dilihat dengan ditetapkannya Mata Pelajaran Matematika sebagai salah satu mata pelajaran yang ada pada Ujian Nasional (UN). Dalam pembelajaran Matematika salah satu kemampuan matematika adalah kemampuan pemecahan masalah matematis.Kemampuan Pemecahan masalah merupakan salah satu kemapuan yang harus dikusai dalam pembelajaran matematika, karena merupakan tipe belajar yang paling tinggi tingkatannya. Menurut Lestari dan Yudhanegara (2017:84) Kemampuan Pemecahan Masalah adalah kemampuan menyelesaikan masalah rutin, non-rutin, rutin terapan, rutin non terapan, non-rutin terapan, dan masalah non-rutin non-terapan dalam bidang matematika.

Ada beberapa model pembelajaran yang dalam proses pembelajarannya mengutamakan adanya kelompok-kelompok dalam pembelajaran. Diantara model pembelajaran tersebut, salah satunya adalah model pembelajaran Group Investigation (GI). Model Pembelajaran Group Investigation (GI) adalah salah satu model pembelajaran yang melakukan perencanaan dan penyelesaian masalah yang di hadapi. Pada Lestari dan Yudhanegara (2017:50) model Pembelajaran Group Investigation (GI) menuntut semua anggota kelompok untuk merencanakan suatu penelitian beserta nerencanakan penyelesaian masalah yang dihadapi. Kelompok menentukan apa saja yang akan dikerjakan dan siapa saja yang akan melaksanakannya serta bagaimana perencanaan penyajian di depan kelas. Adapun menurut Agus Suprijono (2014:93) dalam bukunya menuliskan bahwa pembelajaran dengan model Group Investigation (GI) di mulai dengan pembagian kelompok. Selanjutnya guru beserta siswa memilik topik-topik tertentu dengan permasalahan-permasalahan yang dapat dikembangkan dari topik-topik itu. Sesudah topik beserta permasalahannya disepakati, peserta didik beserta guru menentukan metode penelitian yang dikembangkan untuk memecahkan masalah. Dalam kegiatan pada model pembelajaran Group Investigation (GI) sudah mencangkup kemampuan pemecahan masalah dan kepercayaan diri siswa. Hal tersebut juga diperkuat dengan adanya beberapa penelitian yang telah dilakukan mengenai pengaruh model Group Investigation (GI) terhadap kemampuan pemecahan masalah dan model Group Investigation (GI) terhadap percaya diri siswa. Salah satu dari beberapa penelitian tersebut yaitu penelitian yang dilakukan oleh Aditya (2017) yaitu Pengaruh Model Pembelajaran (GI) Group Investigation Terhadap Kemampuan Pemecahan Masalah Matematika dan Motivasi Belajar Siswa di SMP N 2 Kutasari Kelas VII tahun 2017 dan Penelitian yang dilakukan Erfan Sufena, dkk (2018) yaitu Pengaruh Penerapan Metode Kooperatif Tipe Investigasi Kelompok (Group Investigation) Terhadap Kemampuan Komunikasi Matematis dan Percaya Diri Siswa, dari penelitian tersebut peneliti menyimpulkan bahwa Percaya Diri Siswa yang belajar menggunakan metode Group Investigation lebih tinggi dibandingkan siswa yang mendapatkan pembelajaran konvensional.

Berdasarkan latar belakang yang telah dijelaskan di atas yang telah diperkuat dengan hasil beberapa penelitian, penulis ingin mengetahui pengaruh dari pembelajaran Tipe Group Investigation (GI) terhadap kemampuan pemecahan masalah matematika dan percaya diri siswa kelas VII SMP Negeri 2 Rembang.

\section{Metode Penelitian}

Penelitian ini menggunakan desain penelitian Posttest Only Control Design. Populasi pada penelitian ini adalah seluruh kelas VII SMP Negeri 2 Rembang, Kecamatan Rembang Kabupaten Purbalingga semester genap tahun pelajaran 2017/2018. Teknik pengambilan sampel yang digunakan dalam penelitian ini adalah Cluster Random Sampling yaitu 
pengambilan sampel secara acak dari kelompok populasi. Sampel pada penelitian ini diambil dua kelas yang akan dijadikan kelas eksperimen dan kelas kontrol. Kelas eksperimen yaitu kelas yang menggunakan pembelajaran Group Investigation, sedangkan kelas control yaitu kelas yang menggunakan pembelajaran langsung.

Teknik pengumpulan data pada penelitian ini diperoleh melalui metode tes, metode tes dan non tes. Tes dan non tes di lakukan pada akhir perlakuan kelas eksperimen dan kelas kontrol. Instrumen yang digunakan dalam penelitian ini berupa tes kemampuan pemecahan masalah matematis siswa yang berbentuk uraian dan untuk mengukur percaya diri siswa berupa soal angket percaya diri . Tes kemampuan pemecahan masalah matematis disusun berdasarkan langkah-langkah pemecahan masalah matematis. Tes diuji cobakan kepada kelas yang telah menerima materi. Uji coba instrument bertujuan untuk mengetahui validitas dan reliabilitas soal, sehingga soal dapat digunakan dalam penelitian untuk mengukur kemampuan pemecahan masalah matematis siswa dan percaya diri siswa.

Sebelum melakukan uji hipotesis, terlebih dahulu melakukan uji prasyarat yaitu uji normalitas dan homogenitas. Jika kedua data normal dan homogen, maka uji hipotesis menggunakan UjiT. Jika kedua data tidak normal, maka uji hipotesis menggunakan uji non parametris Uji-U yaitu Mann Whitney. Pengujian dalam penelitian ini menggunakan bantuan program SPSS 21.0

\section{Hasil dan Pembahasan}

Berdasarkan hasil tes yang diperoleh, berikut perbandingan hasil posttest kemampuan pemecahan masalah matematis siswa dan percaya diri siswa antara kelas yang pembelajarannya menggunakan pembelajaran Group Investigation, dengan kelas yang pembelajarannya menggunakan pembelajaran langsung.

Dalam uji normalitas, kriteria pengujiannya adalah jika data berdistribusi normal jika sig. $\geq \alpha$, dengan $\alpha=0,05$ yang artinya $H_{0}$ : diterima. Hipotesis yang digunakanyaitu:

$H_{0}$ :Data berdistribusi normal jika nilai sig. $\geq \alpha$

$H_{a}$ :Data tidak berdistribusi normal jika nilai sig. $<\alpha$

Tabel 4.1 Hasil Uji Normalitas Posttest

\section{Tests of Normality}

\begin{tabular}{|c|c|c|c|c|c|c|}
\hline \multirow[t]{2}{*}{ Kelas } & \multicolumn{3}{|c|}{ Kolmogorov-Smirnov ${ }^{\mathrm{a}}$} & \multicolumn{3}{|c|}{ Shapiro-Wilk } \\
\hline & Statistic & $\mathrm{df}$ & Sig. & Statistic & Df & Sig. \\
\hline nilai post test &, 151 & 35 &, 042 & ,945 & 35 &, 079 \\
\hline $\begin{array}{l}\text { kelas eksperimen } \\
\text { nilai post test }\end{array}$ & , 108 & 35 & ,200* & 962 - r & 35 & 261 \\
\hline kelas kontrol & & & & & & \\
\hline
\end{tabular}

*. This is a lower bound of the true significance.

a. Lilliefors Significance Correction 
Tabel 4.2 Hasil Uji Normalitas Angket Percaya Diri

\begin{tabular}{|c|c|c|c|c|c|c|}
\hline \multicolumn{7}{|c|}{ Tests of Normality } \\
\hline & \multicolumn{3}{|c|}{ Kolmogorov-Smirnov $^{\mathrm{a}}$} & \multicolumn{3}{|c|}{ Shapiro-Wilk } \\
\hline & Statistic & $\mathrm{df}$ & Sig. & $\begin{array}{c}\text { Statisti } \\
\text { c }\end{array}$ & df & Sig. \\
\hline $\begin{array}{l}\text { Hasil angket } \\
\text { kelas } \\
\text { eksperimen }\end{array}$ &, 127 & 35 & ,169 & ,967 & 35 & ,377 \\
\hline $\begin{array}{l}\text { Hasil angket } \\
\text { kelas kontrol }\end{array}$ & , 101 & 35 & ,200* & ,926 & 35 & ,022 \\
\hline
\end{tabular}

*. This is a lower bound of the true significance.

a. Lilliefors Significance Correction

Berdasarkan hasil uji normalitas untuk hasil posttest dengan program SPSS diperoleh nilai signifikansi pada kelas eksperimen sebesar 0,042. Hal ini menunjukkan nilai sig. $\leq 0,05$ maka $_{0}$ :ditolak atau dapat dikatakan data posttest kemampuan pemecahan masalah matematis siswa pada kelas eksperimen tidak berdistribusi normal. Sedangkan nilai signifikansi pada kelas control sebesar 0,200. Hal ini menunjukkan 0,200 $\leq 0,05$, maka $H_{0}$ : diterima atau dapat dikatakan data posttest kemampuan pemecahan masalah matematis siswa kelas control berdistribusi normal. Karena data kelas eksperimen tidak berdistribusi normal maka uji statistik yang digunakan adalah uji non parametris yaitu uji Mann Whitney pihak kanan. Sedangkan berdasarkan hasil uji normalitas untuk hasil angket percaya diri dengan program SPSS diperoleh nilai signifikansi pada kelas eksperimen sebesar 0,169 . Hal ini menunjukkan nilai sig. $\geq 0,05$ maka $H_{0}$ :diterima atau dapat dikatakan data angket percaya diri siswa pada kelas eksperimen

berdistribusi normal. Sedangkan nilai signifikansi pada kelas control sebesar 0,200. Hal ini menunjukkan $0,200 \leq 0,05, \operatorname{maka}_{0}$ : diterima atau dapat dikatakan data angket percaya siswa kelas control berdistribusi normal. Karena data kedua kelas berdistribusi normal maka uji statistik yang digunakan adalah uji independent $\mathrm{T}$ test. Adapun hipotesis yang digunakan dalam pengujian ini adalah :

$H_{0}: \mu_{1} \leq \mu_{2}$ : Rata - rata kemampuan pemecahan masalah matematis siswa yang menggunakan pembelajaran Group Investigation lebih rendah atau sama dengan kemampuan pemecahan masalah matematis siswa yang mengikuti pembelajaran langsung.

$H_{a}: \mu_{1}>\mu_{2}$ : Rata-rata kemampuan pemecahan masalah matematis siswa yang menggunakan pembelajaran Talking Stick lebih baik dari pada kemampuan komunikasi matematis siswa yang mengikuti pembelajaran langsung.

Dan untuk angket percaya diri, hipotesis yang digunakan adalah :

$H_{0}: \mu_{1} \leq \mu_{2}$ : Rata-rata percaya diri siswa yang menggunakan pembelajaran Group Investigation lebih rendah atau sama dengan percaya diri siswa yang mengikuti pembelajaran langsung.

$H_{a}: \mu_{1}>\mu_{2}$ : Rata-rata percaya diri siswa yang menggunakan pembelajaran Talking Stick lebih baik dari pada percaya diri siswa yang mengikuti pembelajaran langsung. 
Berikut hasil uji hipotesis dengan uji Mann Whitney untuk hasil posttest dan uji Independent $\mathrm{T}$ test untuk angket percaya diri yang dibantu dengan program SPSS

Tabel 4.3 Tabel Uji Hipotesis Uji Mann Whitney Post Test

Kemampuan Pemecahan Masalah

Test Statistics ${ }^{\mathbf{a}}$

\begin{tabular}{lr}
\hline & hasil post test \\
\hline Mann-Whitney U & 459,500 \\
Wilcoxon W & 1089,500 \\
Z & $-1,808$ \\
Asymp. Sig. (2- &, 071 \\
tailed) & \\
\hline a. Grouping Variable: kelas
\end{tabular}

Berdasarkan data posttest kemampuan pemecahan masalah pada kelas eksperimen dan kelas kontrol adalah normal dan homogen. Sehingga pengujian hipotesis dilakukan dengan mann whitney menggunakan SPSS 21. Selanjutnya ditunjukkan pada tabel 4.18 di atas bahwa didapat hasil Asymp. Sig. $=0,071$ yang berarti Sig. $>\alpha=0,05$ maka asumsi kedua varaians sama besar (equal variances assumed) terpenuhi. Karena uji hipotesis yang digunakan adalah uji satu sisi (one tailed) untuk sisi atas (upper tailed), sedangkan pada output SPSS yang ditampilkan adalah Sig(2-tailed) maka $H_{0}$ diterima jika $\frac{\text { Sig.(2-tailed) }}{2}$ lebih dari $\alpha=0,05$. Hasil pengujian hipotesis didapatkan nilai Sig. $(2$-tailed $)=0,012$ sehingga didapatkan Sig. = $\frac{0,071}{2}=0,0355$. Karena nilai Sig. $=0,0355$ lebih kecil dari $\alpha=0,05$ maka $H_{0}: \mu_{d 1} \leq \mu_{d 2}$ ditolak. Sehingga dapat ditarik kesimpulan bahwa rata-rata kemampuan pemecahan masalah siswa yang mengikuti pembelajaran kooperatif tipe Group Investigationlebih baik dibandingkan dengan rata-rata kemampuan pemecahan masalah siswa yang mengikuti pembelajaran langsung. 
Tabel 4.4 Tabel Uji Hipotesis Independent Sample t Test pada Data

Angket Percaya Diri

Berdasarkan tabel 4.4, data angket percaya diri pada kelas eksperimen dan kelas kontrol adalah normal dan homogen. Sehingga pengujian hipotesis dilakukan dengan uji independent

\section{Independent Samples Test}

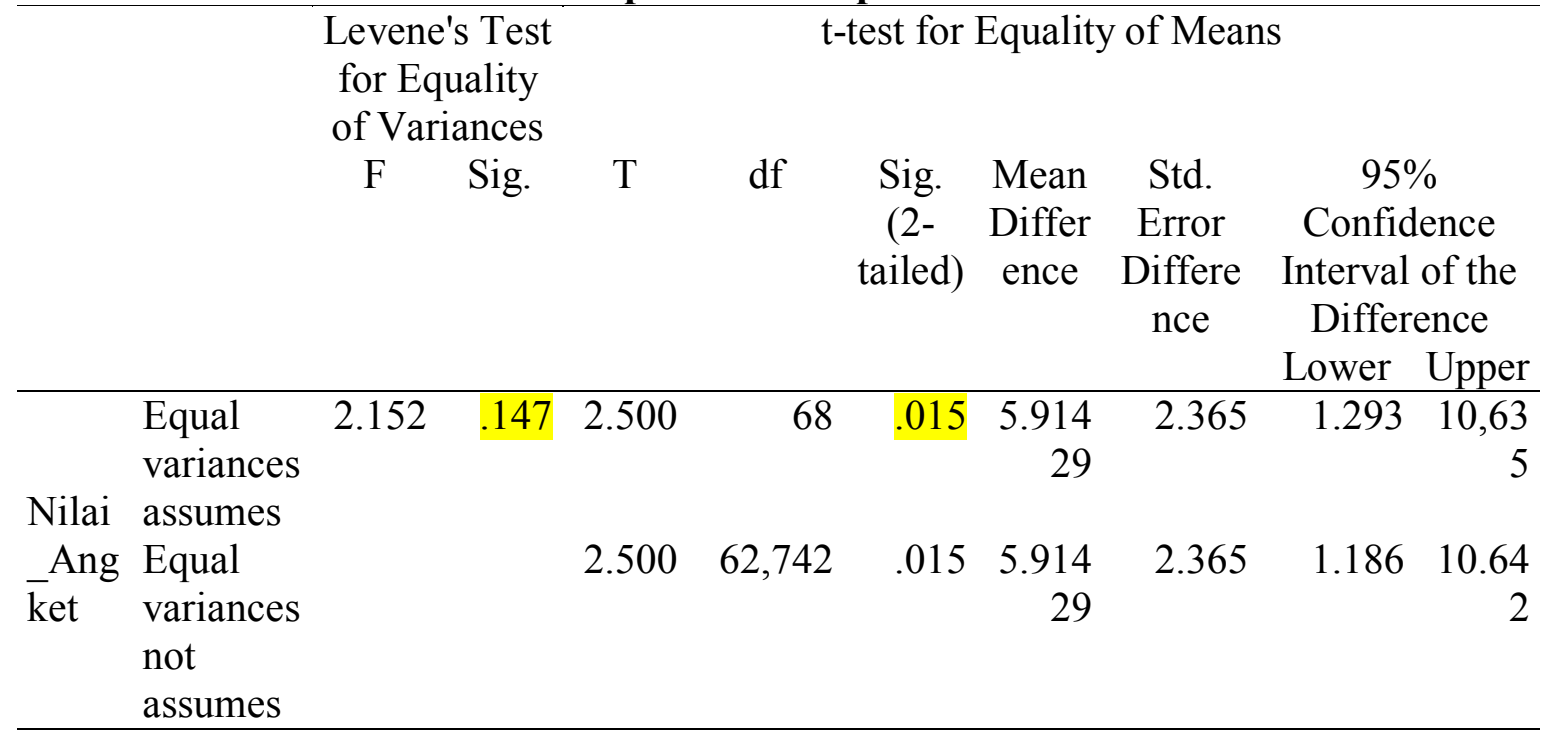

sample $\mathrm{t}$ test menggunakan SPSS 21. Selanjutnya ditunjukkan pada tabel 4.19 di atas bahwa didapat hasil Levene's Test yaitu Sig. $=0,147$ yang berarti Sig. $>\alpha=0,05$ maka asumsi kedua varaians sama besar (equal variances assumed) terpenuhi. Berdasarkan itu, maka nilai Sig. (2tailed) diambil dari baris equal variances assumed untuk hipotesis $H_{0}: \mu_{d 1} \leq \mu_{d 2}$ terhadap $H_{a}: \mu_{d 1}>\mu_{d 2}$ yang memberikan nilai $\mathrm{t}=2,592$ dengan derajat kebebasan $n_{1}+n_{2}-2=35+35-$ $2=68$ dan Sig. $(2$-tailed $)=0,015$. Karena uji hipotesis yang digunakan adalah uji satu sisi (one tailed) untuk sisi atas (upper tailed), sedangkan pada output SPSS yang ditampilkan adalah $\operatorname{Sig}\left(2\right.$-tailed) maka $H_{0}$ diterima jika $\frac{\text { Sig.(2-tailed) }}{2}$ lebih dari $\alpha=0,05$. Hasil pengujian hipotesis didapatkan nilai Sig. $(2-$ tailed $)=0,012$ sehingga didapatkan Sig. $=\frac{0,015}{2}=0,0075$. Karena nilai Sig. $=0,007$ lebih kecil dari $\alpha=0,05$ maka $H_{0}: \mu_{d 1} \leq \mu_{d 2}$ ditolak. Sehingga dapat ditarik kesimpulan bahwa rata-rata percaya diri siswa yang mengikuti pembelajaran kooperatif tipe Group Investigation lebih baik dibandingkan dengan rata-rata percaya diri siswa yang mengikuti pembelajaran langsung

\section{Simpulan}

Berdasarkan hasil uji hipotesis, Diperoleh nilai sig pada uji Mann Whitney untuk hasil posttest sebesar 0,0355 dan nilai sig pada uji Independent t Test untuk hasil angket sebesar 0,0075 nilai dari kedua uji tersebut kurang dari $\alpha(0,05)$, Sehingga mengakibatkan H0 ditolak dan Ha diterima. Jadi dapat disimpulkan kemampuan pemecahan masalah matematis dan percaya diri siswa yang mengikuti pembelajaran kooperatif tipe Group Investigation lebih 
baik dibandingkan dengan kemampuan pemecahan masalah matematis dan percaya diri dengan menggunakan pembelajaran langsung.

Berdasarkan penelitian yang telah dilakukan peneliti menyarankan agar model pembelajaran kooperatif tipe Group Investigation dapat menjadi salah satu model yang dapat sering digunakan digunakan karena dapat menumbuh kembangkan kemampuan yang sangat penting yaitu komunikasi matematis, selain itu model pembelajaran kooperatif tipe Group Investigation juga dapat mengembangkan percaya diri siswa yang dapat mendukung keberhasilan dalam mencapai tujuan pembelajaran.

\section{Daftar Pustaka}

Aditya, (2017). Pengaruh Model Pembelajaran (GI) Group Investigation terhadap Kemampuan Pemecahan Masalah Matematis dan Motivasi Belajar Siswa di SMP N 2 Kutasari Kelas VII tahun 2017. UMP. Tidak diterbitkan.

As'ari, Rahman, A, dkk, (2017). Matematika edisi revisi 2017 SMP/MTs Kelas VII Semester 2. Jakarta : Pusat Kurikulum dan Perbukuan, Balitbang, Kemendikbud.

Arikunto, suharsimi (2015). Dasar-dasar Evaluasi Pendidikan. Jakarta : PT Bumi Aksara

Dewanda, (2017). Pengaruh Pembelajaran Group Investigation dengan Strategi Pemecahan Masalah IDEAL terhadap Kemampuan Berpikir Kritis Matematis Siswa SMP Negeri 4 Sumbang. UMP. Tidak diterbitkan.

Gangga, U. W. A., Kusmayadi, T. A., \& Usodo, B. (2015). Eksperimentasi Model Problem Based Learning (Pbl) Dan Model Group Investigation (Gi) Dalam Pembelajaran Matematika Materi Bangun Ruang Sisi Datar Ditinjau Dari Sikap Percaya Diri Siswa Kelas VIII SMP Se-kabupaten Madiun Tahun Pelajaran 2013/2014.

Lestari.E.K dan Yudhanegara.R.M. (2017). Penelitian Pendidikan Matematika. Bandung : PT Refika Aditama.

Mustari, Mohamad. (2014). Nilai Karakter Refleksi untuk Pendidikan. Depok : PT Rajagrafindo Persada.

Shoimin, Aris. (2014). 68 Model Pembelajaran Inovatif dalam Kurikulum 2013. Yogyakarta : Ar-Ruzz Media

Slavin, Rt. (2005). Cooperative Learning : Teori, Riset dan Praktik. Bandung : Nusa Media

Sufena, E., Suyono, S., \& El Hakim, L. (2018). Pengaruh Penerapan Metode Kooperatif Tipe Investigasi Kelompok Terhadap Kemampuan Komunikasi Matematis dan Self Confidence Siswa SMP. Journal of Mathematics Learning, 1(1), 27-38. 


\section{KHOTIJAH PRIYATIN}

Pengaruh Pembelajaran Kooperatif Tipe Group Investigation (GI) Terhadap Kemampuan Pemecahan Masalah Matematis Dan Percaya Diri Siswa SMP Negeri 2 Rembana

Suprijono,A. (2014). Cooperatife Learning. Yogyakarta : Pustaka Pelajar.

Uyanto, (2006). Pedoman Analisis Data dengan SPSS. Yogyakarta: Graha Ilmu 